Abstracta Iranica Iranica

Revue bibliographique pour le domaine irano-aryen

Volume 34-35-36 | 2017

Comptes rendus des publications de 2011-2013

\title{
Bruno Overlaet. Ahura Mazda and Shapur II? A Note on Taq-i Bustan, the Investiture of Ardashir II (379-383)
}

\section{Barbara Kaim}

\section{(2) OpenEdition}

1 Journals

Édition électronique

URL : http://journals.openedition.org/abstractairanica/42318

DOI : 10.4000/abstractairanica.42318

ISSN : 1961-960X

\section{Éditeur :}

CNRS (UMR 7528 Mondes iraniens et indiens), Éditions de l'IFRI

\section{Référence électronique}

Barbara Kaim, « Bruno Overlaet. Ahura Mazda and Shapur II? A Note on Taq-i Bustan, the Investiture of Ardashir II (379-383) », Abstracta Iranica [En ligne], Volume 34-35-36 | 2017, document 41, mis en ligne le 30 juillet 2017, consulté le 02 octobre 2020. URL : http://journals.openedition.org/abstractairanica/ 42318 ; DOI : https://doi.org/10.4000/abstractairanica.42318

Ce document a été généré automatiquement le 2 octobre 2020.

Tous droits réservés 


\title{
Bruno Overlaet. Ahura Mazda and Shapur II? A Note on Taq-i Bustan, the Investiture of Ardashir II (379-383)
}

\author{
Barbara Kaim
}

\section{RÉFÉRENCE}

Bruno Overlaet. « Ahura Mazda and Shapur II? A Note on Taq-i Bustan, the Investiture of Ardashir II (379-383) ». IA, 47, 2012, p. 133-151.

1 Le relief de Taq-i Bustan et surtout les deux personnages masculins représentés ici sur la dépouille d'un empereur romain ont connu de nombreuses interprétations. L'homme debout à droite tenant le barsom et l'anneau enrubanné dans sa main est interprété comme le dieu Ahura Mazda ou bien comme Shapur II, vainqueur de l'empereur romain Julien, qui se trouve sous les pieds des hommes. Le monarque qui tend la main droite vers le diadème tandis que sa main gauche est posée sur son épée peut être Shapur II ou, selon une autre interprétation, Ardashir II, qui pendant les combats avec les Romains était roi-gouverneur de l'Adiabène puis en 379 succédait à Shapur II. Selon l'A, la scène représente Ardashir qui reçoit la royauté de Shapur II. La représentation de Shapur II est un mélange délibéré de l'iconographie d'Ahura Mazda et de celle de ce roi. 


\section{AUTEURS}

BARBARA KAIM

Université de Varsovie 